\title{
VÍTIMAS FATAIS DO SALAZARISMO: REALIDADE E FICÇÃO EM BALADA DA PRAIA DOS CÃES: DISSERTAÇÃO SOBRE UM CRIME (1982), DE JOSÉ CARDOSO PIRES
}

Resumo: O objetivo do estudo é apresentar as variadas facetas da realidade e da ficção do crime do Guincho (1960) - o assassinato do capitão Almeida Santos, um dos líderes do Golpe da Sé (1959) para derrubar a ditadura de Salazar - que abalou a opinião pública portuguesa e motivou a escrita da Balada da Praia dos Cães (1982), de José Cardoso Pires. A narrativa polifônica (Bakhtin), que será analisada segundo reflexões de Hutcheon e Todorov, evoca o ambiente de medo e violência em Lisboa, e revela a ruptura de paradigmas consagrados do romance, ao mesclar variados registros: dossiês policiais, autos e relatórios com jargões e técnicas de inquérito e de medicina legal forenses; textos e intertextos: notas de rodapé explicativas sobre a biografia de personagens e eventos históricos, notícias de jornais, panfletos etc.

Palavras-chave: Literatura portuguesa; José Cardoso Pires; Balada da Praia dos Cães; história; polifonia.

\section{FATAL VICTIMS OF SALAZARISM: REALITY AND FICTION IN THE BAY OF THE DOGS 'BEACH: DISSERTATION ABOUT A CRIME (1982), DE JOSÉ CARDOSO PIRES}

\begin{abstract}
The aim of the study is to present the various facets of reality and fiction of beach crime of Guincho (1960) - the assassination of captain Almeida Santos, one of the leaders of the Coup de la Sé (1959) to overthrow Salazar 's dictatorship - the Portuguese public opinion and that motivated the writing of the Ballad of the Beach of the Dogs (1982), of Jose Cardoso Pires. The polyphonic narrative (Bakhtin), which will be analyzed according to Hutcheon and Todorov's reflections, evokes the atmosphere of fear and violence in Lisbon, and reveals the rupture of established paradigms of the novel, merging varied records: police files, reports and reports with jargon and forensic legal research and medicine; texts and intertexts: explanatory footnotes on the biography of characters and historical events, news from newspapers, leaflets, etc.
\end{abstract}

Keywords: Portuguese literature; José Cardoso Pires; Ballad of the Beach of the Dogs; history; polyphony.

\section{Introdução}

[...] as investigações para identificação de um cadáver descoberto anteontem na praia do Guincho, perto de Lisboa, permite suspeitar de que se trata do capitão Almeida Santos, um dos evadidos da prisão militar de Elvas, em Dezembro último, onde estava encarcerado por actividades políticas contra o regime. (AFP apud SENA, 1998, p. 1).

\footnotetext{
${ }^{1}$ Formação em Magistério, graduação em Letras e doutorado em Literatura e Vida Social na UNESP, Assis. Bacharelado em História e Magister Artium na Ruprecht-Karls Universität Heidelberg, Alemanha. PósDoutorado na UEL, Londrina/PR e na UFC. Professora na UFC, Fortaleza, Centro de Humanidades.
} 
O excerto acima citado, oriundo do telegrama expedido pelo órgão oficial de comunicação, e distribuído à impressa pela AFP (Agence France Presse) em Portugal, no dia 2 de abril de 1960, revela uma das facetas da ditadura portuguesa, a da captura, aprisionamento e morte de dissidentes, como o capitão de cavalaria José Joaquim Almeida Santos. Ele foi um dos principais líderes de uma conspiração frustrada contra o governo de Salazar ("Golpe da Sé”, 1959), que aguardava julgamento no Presídio Militar da Graça, em Elvas, de onde fugiu com dois cúmplices: João Jacques Marques Valente, oficial médico, e António Marques Gil, cabo. Este era membro da Guarda Nacional Republicana (GNR) e atuou como o carcereiro que facilitou a evasão.

Os jornais portugueses da época - Diário de Notícias, O Século, Diário Popular e Diário da Manhã - noticiaram que o corpo do ex-capitão tinha sido encontrado na praia do Guincho, em 31 de março de 1960. Esse crime, inicialmente, foi interpretado como político: A eliminação, por forças repressoras da Polícia Internacional e de Defesa do Estado (PIDE), do traidor de farda, que criticou a ditadura salazarista e tentou tirá-la do poder e, ainda mais, conseguiu arregimentar parceiros dentro da carceragem, como o cabo Gil, com a ajuda do qual conseguiu escapar, juntamente com Valente, desnudando as falhas do sistema prisional militar.

O escritor e jornalista Jorge de Sena (1919-1978) escreveu o editorial Os Dois Cadáveres, do jornal Portugal Democrático. Publicado na edição de abril de 1960, o textomanifesto de Sena estabelece uma analogia entre o corpo de Portugal e o do capitão Almeida Santos, cidadão patriota e militar, ao mesmo tempo que ataca o chefe de estado, reduzindo-o à condição de um cadáver insepulto:

Tu, Salazar, [...] serás um cadáver, hás-de ser um cadáver, terás de ser um cadáver. Não um cadáver hipotético - como o da Pátria ensanguentada abandonado, tão ocasionalmente, numa praia deserta. Mas um cadáver consola-te que não terá tempo de apodrecer, como o da Pátria em trinta anos de governo teu. Um cadáver que a terra portuguesa se recusará a comer. Um cadáver que os mares de Portugal - e todos são - se recusarão a engolir. (SENA, 1998, p. 1)

No decorrer da investigação, realizada por Francisco Correia das Neves (1929-2017), inspetor da Polícia Judiciária (PJ) de Lisboa, pelo inspetor- adjunto José Aurélio Boim Falcão e pelo agente Ślvio da Costa Mortágua da PIDE, constatou-se que o homicídio não fora cometido por forças salazaristas, mas, sim, por pessoas próximas da vítima: Maria José Maldonado Sequeira, a amante do capitão, e os dois cúmplices da fuga, o oficial Valente e o 
cabo Gil. O advogado de Almeida Santos, Cunha Leão, desapareceu e foi preso como suspeito.

Esse fato histórico vai constituir o embasamento do romance Balada da Praia dos Cães: Dissertação sobre um crime (1982), de José Cardoso Pires, que foi escrito depois da Revolução dos Cravos (1974), a qual libertou Portugal da tirania instalada por Salazar, nos anos 19321968. Falecido em 1970, ele foi sucedido por Marcello Caetano. Na Nota final da narrativa, Cardoso Pires esclarece que:

Em certas vidas (eu acrescentaria, em todas) há circunstâncias que projectam o indivíduo para significações do domínio geral. Um acaso pode transformá-lo em matéria universal - matéria histórica para uns, matéria de ficção para outros, mas sempre justificativa de abordagem. Interrogamo-la, essa matéria, porque ele nos interroga no fundo de cada um de nós - foi assim que pensei esse livro, um romance. Nele, o arquiteto Fontenova é uma personagem literária, e da mesma maneira o major. E Mena. Todos são personagens literárias, isto é, dissertadas de figuras reais.

De modo que entre o facto e a ficção há distanciamentos e aproximações a cada passo, e tudo se pretende num paralelismo autónomo e numa confluência conflituosa, numa verdade e numa dúvida que não são pura coincidência. (PIRES, 1983, p. 256).

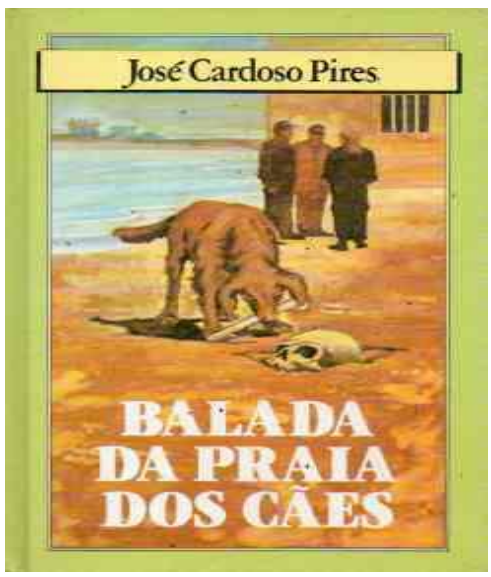

Fig. 1- Capa do romance, Editora Círculo do Livro, 1991.

Balada da Praia dos Cães, de José Cardoso Pires, ${ }^{2}$ aborda, com licença poética, a trajetória de alguns críticos capturados pela polícia da ditadura: preso por conspiração

\footnotetext{
${ }^{2}$ José Augusto Cardoso Pires (1925-1998) começou sua carreira literária com a publicação de contos: Os caminheiros e outros contos (1949), além de Histórias de amor (1952), Jogos de Azar (1963), O Burro em Pé (199) e A República dos Corvos (1988). Lançou seu primeiro romance, em 1958, O Anjo Ancorado, com críticas sociais e aspectos alegóricos. Seguem: O hóspede de Job (1963), O Delfim (1968) e Alexandra Alpha (1987). No ano de 1960, publica a peça teatral O Render dos Heróis, baseado em um fato histórico, e Corpo de Delito na Sala da Espera (1980), peça teatral sobre a atuação da PIDE (Polícia Internacional e de Defesa do Estado). Escreveu
} 
contra o estado de Salazar, o major Luís Dantas Castro (capitão José Joaquim de Almeida Santos), casado e pai de família, planeja a sua evasão do cárcere militar de Elvas com o oficial e arquiteto miliciano Renato Manuel Fontenova (o oficial e médico João Jacques Marques Valente); ambos cooptam o simplório cabo Bernadino Barroca (António Marques Gil), de origem rural, que acreditava que todos iriam para a França. A estudante universitária Filomena Joana Van Niel de Athaide, conhecida como Mena (Maria José Maldonado Sequeira, a Zezinha), amante do major, organizou a fuga, ocorrida na noite do dia 31 de dezembro para o $1^{\circ}$ de janeiro de 1960. Os quatro passam a viver na Casa da Vereda, próxima da povoação de Fornos, Cascais, na angustiante espera por recebimento de ajuda externa, como documentos falsos, dinheiro e rota de fuga planejada para fora do país. Mena, que penhorou algumas jóias pessoais para poder comprar mantimentos, adquiridos nas imediações, era viciada em Valium e tabaco e começou a temer por sua vida, diante da decadência psicológica do amante opressor.

No romance, o elo exterior do grupo, além de Filomena, deveria ser o Comodoro, o advogado Gama e Sá (Cunha Leão), que iria atuar na defesa do prisioneiro principal, o major Dantas Castro. Este, no entanto, foi assassinado antes do início do julgamento. Os simpatizantes do movimento para derrubada de Salazar, como o advogado Sá, entretanto, não querem se envolver com Dantas, cuja vida tinha se complicado ainda mais com a fuga tresloucada. Desesperado e imerso no álcool, o major reconhece a causa perdida e começa a escrever um caderno e uma lista negra, com os nomes dos traidores da mobilização em prol da redemocratização de Portugal, bem como os dos generais corruptos e passa a atormentar os três, de arma em punho.

O confinamento planejado por ele extrai de sua personalidade o pior: a faceta de algoz impiedoso e debochador, que inferniza a todos. Dantas reproduz no esconderijo dois tipos de desmandos vigentes na sociedade portuguesa da época: a violência machista contra a mulher (a amante) e a violência político-militar em relação aos dois companheiros. Faz sessões de tortura com Mena, com cigarro aceso nas costas e até queimaduras no rosto com lâmpada ligada. Além de humilhar o cabo Barroca, por deixar a barba crescer e por

os ensaios: Cartilha do Marialva (1960), O Dinossauro Excelentíssimo (1972), com alusões a Salazar (morto em 1970); E agora, José (1977), textos reflexivos sobre o passado recente de Portugal. E as crônicas: Cardoso Pires por Cardoso Pires (1991), A Cavalo no Diabo (1994), De Profundis, Valsa Lenta (1997) e Lisboa, Livro de Bordo (1997). 
estudar francês com a ajuda de Fontenova. Com este, ele comenta que tem planos para assassinar a jovem, inclusive mostra o local adequado para enterrar o corpo.

Dantas sai, disfarçado de padre, e simula encontros com o seu advogado e colegas militantes. Seu sentimento de abandono é tamanho, que ele intensifica o terrorismo na vida de todos, mas os dois militares, já desesperançados por mudanças e acuados pelas ameaças letais, premeditam o crime e o acertam sorrateiramente, com tiros. Filomena não sabia dos planos de assassinato, mas ao ouvir os gritos do major, foi coagida a atingir o amante que ainda estava vivo. O cadáver do decaído líder foi enterrado na praia do Mastro (praia do Guinçho) e descoberto por cães, cujos latidos chamaram a atenção de um pescador.

O título da obra, Balada da Praia dos Cães, que evoca o assassinato do capitão Almeida Santos (1960), remete ao:

\begin{abstract}
Cantar de feição narrativa, girava ao redor de um único episódio, de assunto melancólico, histórico, fantástico ou sobrenatural. $\mathrm{Na}$ verdade, trata-se de "forma literária mista, pois reúne elementos de poesia dramática e lírica bem como de narrativa. Mas em geral pode ser descrita como uma breve canção-história (era normalmente cantada), que vai direto ao ponto, emprega escassos detalhes, e via de regra sugere mais do que explora largas porções do enredo. O processo dramático de pergunta-reposta, ou diálogo, é geralmente utilizado para desenvolver a fabulação, e a chave do seu desenlace frequentemente se adia até próximo do fim" (Zilma 1967: 29) (MOISÉS, 2004, p. 49)
\end{abstract}

A respeito da escolha do nome de seu romance, Pires, em entrevista concedida ao Jornal de Letras, no . 47, edição de 7 a 20 dez. 1982, explicou: "Balada porque à maneira das baladas inglesas, o que eu pretendi foi escrever sobre um acontecimento real já tocado pela lenda". (JOSÉ, 1982, p. 2 e 3). Trata-se de um crime histórico (1960), cuja engrenagem permeia a ditadura de Salazar, a partir do Golpe da Sé (1959) para derrubar o regime instaurado em 1932.

O objetivo do estudo Vitimas fatais do salazarismo é apresentar as faces da realidade e da ficção do crime do Guincho (1960), o assassinato do capitão Almeida Santos e sua elucidação. A narrativa revela a ruptura de paradigmas consagradas do romance, ao mesclar variados registros: dossiês policiais, autos e relatórios com jargões e técnicas de inquérito e de medicina legal forenses; textos e intertextos: notas de rodapé explicativas sobre a biografia de personagens e eventos históricos, notícias de jornais, panfletos etc.

Balada da Praia dos Cães, que tem como subtítulo Dissertação sobre um crime, será analisado segundo as reflexões do romance histórico (Hutcheon), do romance polifônico 
(Bakhtin) e do romance criminal, ao evocar um momento de terror em Lisboa e adjacências, envolto no clima de opressão ditatorial do governo de António Salazar.

\section{0 salazarismo (1932-1968) e a opressão}

Os anos 1950, em Portugal, caracterizam-se como uma época de aguerrida perseguição a dissidentes, que se colocavam diametralmente opostos à ditadura civil de Antonio de Oliveira Salazar (1889-1970), denominada de Estado Novo, que estava fragilizado pelas primeiras inquietações nas suas colônias africanas, em prol das lutas pela independência. A questão das colônias é camuflada com a promulgação da Lei n. 2.066, que extingue o termo "Império Colonial Português" e cria a expressão "Províncias Ultramarinas", em 27 de junho de 1953. Nesse mesmo ano, surge a revolta nativa de São Tomé, seguida por outras, como o movimento dos "satyagrahis" em Goa (1954). No Timor Português, os colonizadores lusos reprimem a revolta popular (1959).

A legitimação do governo salazarista, no caso da política externa, ocorre com a participação na Reunião do Conselho da Organização do Tratado do Atlântico Norte (OTAN), em Lisboa, (20-25 de fevereiro de 1952), a aprovação do plano de uma Comunidade Europeia de Defesa e a admissão na Organização das Nações Unidas (ONU) (4 de dezembro de 1955). No entanto, existiam denúncias estrangeiras de abusos cometidos na Colónia Penal do Tarrafal, em Cabo Verde, e em consequência disso, ela foi fechada em 26 de janeiro de 1954.

O aparato repressivo da ditadura civil, apoiado principalmente pelo Exército e pela Legião Portuguesa, é constituído pela PIDE (Polícia Interna e de Defesa do Estado), criada como PVDE (Polícia de Vigilância e de Defesa do Estado), em 1933; pela PSP (Polícia de Segurança Pública); pela GNR (Guarda Nacional Republicana, uma unidade de combate às greves) e, pela Guarda Fiscal, conforme acentua Lincoln Secco na obra A Revolução dos Cravos e a crise do império colonial português: economias, espaços e tomadas de consciências. (SECCO, 2004, p. 55). Esses órgãos repressivos controlavam os sindicatos e combatiam, implacavelmente, os dissidentes, principalmente, os membros do Partido Comunista Português, do Seara Nova, e os da Ação Socialista Portuguesa; os atuantes no movimento estudantil e as pessoas marcantes no panorama sociopolítico e cultural como Álvaro Cunhal, General Humberto Delgado, General Norton de Matos, Mário Soares, os escritores Luiz Francisco Rebello, Bernardo Santareno, Luis de Sttau Monteiro, José Cardoso Pires, entre outros. 


\subsection{O golpe da Sé (12 de março de 1959): prisão, fuga e assassinato do capitão José}

\section{Joaquim Almeida Santos}

O capitão José Joaquim Almeida Santos foi um dos principais artífices da tentativa civil e militar pela redemocratização de Portugal, que ficou conhecida como o "Golpe da Sé”, de 12 de março de 1959. Na noite de 11 de março, membros da cúpula organizadora conspiradora se reuniram no claustro da Sé Patriarcal de Lisboa, com a permissão do pároco João Augusto da Costa Perestrello de Vasconcelos, que era militante da causa. Outras unidades estavam agrupadas em locais estratégicos da capital, quando receberam um alarmante sinal de retirada, pois a PIDE tinha recebido notícias sobre a sedição. (PIMENTEL, 2010, p. 1).

De acordo com Filipe Ribeiro de Meneses na obra Salazar: biografia definitiva, um dos mentores da revolta, Manuel Serra, membro da JOC, foi capturado e ganhou notoriedade, quando estava no hospital, em fevereiro de 1960 e conseguiu fugir. Posteriormente, ele pediu asilo na Embaixada do Brasil. (MENESES, 2011, p. 489)

Entre os vários aprisionados encontrava-se o capitão José Joaquim Almeida Santos, que aguardava julgamento no presídio militar de Elvas, onde conseguiu persuadir à fuga outros seguidores - João Jacques Marques Valente, oficial médico, e António Marques Gil, cabo.

Segundo o Acórdão da Secção Criminal do Supremo Tribunal de Justiça de 2 de maio de 1962, a evasão ocorreu no dia 30 de novembro de 1959 e os três passaram por vários esconderijos, até que a amante do capitão, Maria José Sequeira, e sua mãe Adélia Maldonado Sequeira, conseguiram alugar a vivenda Pino Verde, localizada em Rio de Mouro, comarca de Sintra, onde o casal passou a viver desde 25 de fevereiro de 1960.

\subsubsection{O crime (16 de março de 1960)}

Os outros fugitivos, Valente e Gil, foram para a vivenda Pino Verde na noite de 13 para 14 de março do respectivo ano. Na clandestinidade, os ânimos se acirraram, e no dia 16, eles perpetraram o homicídio, cerca das $20 \mathrm{~h}$, quando o capitão estava sentado em um sofá e lia uma carta que tinha recebido:

[...] depois da prévia combinação [...] o réu António Gil, usando da pistola de 6,35 milímetros de que se munira, de surpresa, à queima roupa 
e na intenção de lhe causar a morte, disparou sobre aquele Almeida Santos, um tiro cuja bala se foi localizar na região orbitária esquerda; Em acto contínuo o réu João Jacques puxando do seu revólver de 7,65 milímetros apontou-o contra o mesmo Almeida Santos, a curta distância deste e também na intenção de concorrer para a morte do mesmo, não se tendo disparado esta arma contra a vontade deste réu;

Então o réu António Gil disparou o segundo tiro contra a vítima quando esta já se encontrava prostrada de bruços sobre o soalho atingindo-o na face posterior do braço esquerdo, próximo do cotovelo;

Este gesto de António Gil foi seguido de um outro por parte do réu João Jacques que pegando na pá do fogão de sala, com a mesma agrediu violentamente o Almeida Santos, dando-lhe várias pancadas na nuca e servindo-se da pistola que lhe foi entregue por o António Gil, voluntariamente disparou a mesma contra a sua vítima, atingindo-a na parte média da região parietal;

Verificado por João Jacques que o Almeida Santos ainda não tinha sucumbido a esta agressões, o réu António Gil, na intenção de lhe consumar rapidamente a morte, disparou novamente a pistola contra o coração do mesmo [...] (BALADA, 2012, p. 1)

As duas mulheres, Maria José e sua mãe Adélia, quando ouviram os primeiros tiros, correram para o quintal. Mais tarde participaram da remoção do sangue, queimaram e ocultaram documentos e medalhas da vítima. A pedido de Valente, a jovem ligou para a mãe dele, Renée Marie Rune Marques Valente, com o pedido de levar o carro e seu amigo, Fernando Augusto Albuquerque Mourão, aspirante a oficial do Exército, para o esconderijo, no qual se inteiraram do homicídio. O corpo de Almeida Santos foi levado no Volkswagen, pilotado por Maria José, juntamente com Valente, Gil e Albuquerque, enterrado na praia do Guincho e encontrado no dia 30 de março de 1960. (BALADA, 2012, p. 1)

\section{História, polifonia e assassinato na narrativa híbrida}

Por ocasião do lançamento da obra, o escritor concedeu uma entrevista a Antonio Mega Pereira, publicada no Jornal das Letras, na edição de 7 de dezembro de 1982, com o título O meu romance é uma valsa de conspiradores, na qual acusa o marasmo existente na paisagem política lusa, com dissidentes frouxos em tentativas de oposição mentirosas, participantes de um grande baile-farsa:

[...] o que é verdade e que, durante décadas, houve neste país uma oposição da conspirata profissional, republicanóide e mitómana, cuja fantasia megalómana constituía o melhor campo de treino dos métodos policiais do fascismo. O que se passa naquela casa, onde coabitam aqueles quatro seres é a caricatura (no entanto real) do que foi uma parte 
da conspiração antifascista neste país durante muito tempo. O que era essencial era manter-se o moral, e para isso mentia-se, mentia-se sempre. Mas era o país inteiro que valsava: mentiam os polícias uns aos outros, e os conspiradores, e os jornais, e a propaganda, e os políticos. E todos alegremente se desculpavam da sua realíssima impotência para mudar as coisas. (PIRES, 1982, p. 3).

O ambiente de terror no esconderijo real dos fugitivos do presídio de Elvas, coabitado também pela amante do capitão José Joaquim Almeida Santos, foi compreendido por Cardoso Pires como "a caricatura (no entanto real) do que foi uma parte da conspiração antifascista”. Esta foi ficcionalizada em Balada da Praia dos Cães, que tem características de romance histórico, polifônico e criminal.

\section{$2.1 \mathrm{O}$ romance histórico (Hutcheon)}

O escritor português ficcionaliza o bárbaro homicídio verídico mencionado, e, por meio dele faz um balanço literário, em forma de distintos discursos, sobre as diversas formas da violência: a física, a verbal, a ideológica, a política e a social.

Em relação a diferentes tipos de discursos, Linda Hutcheon em Historicizando o pósmoderno: a problematização da história, componente da obra Poética do pós-modernismo: história, teoria, ficção, escreve:

[...] que a ficção e a história são discursos, que ambas constituem sistemas de significação pelos quais damos sentido ao passado. Em outras palavras, o sentido e a forma não estão nos acontecimentos, mas nos sistemas de significação pelos quais damos sentido ao passado. (HUTCHEON, 1991, p. 122)

O vínculo entre história e ficção é evidente na narrativa de José Cardoso Pires. No outono de 1961, conforme consta na Nota final da obra, o escritor confirmou o recebimento de um relato de 22 páginas, escrito por um condenado [o médico Jean Jacques Marques Valente] ${ }^{3}$ pela co-participação em um homicídio [o de José Joaquim Almeida Santos]. A “descrição lúcida e frontal de uma tragédia” (PIRES, 1983, p. 255) foi enviada a ele por L. V., que se encontrava na embaixada do Brasil, em Lisboa, em asilo político.

Esse texto memorialístico ficou hibernando até 1975, quando o escritor o trabalhou com licença poética: "para dar forma à ideia de usar a história, uma vez que poderia servirse de maiores detalhes nas fichas policiais. [...]. Contudo o que mais me interessava era

\footnotetext{
${ }^{3}$ José Cardoso Pires não cita nominalmente o autor do relato memorialístico sobre o homicídio, na Nota final do romance, mas sabe-se, conforme as notícias veiculadas na imprensa sonora e escrita, e nos autos da investigação e do julgamento, que se trata do oficial médico, Jean Jacques Marques Valente.
} 
demonstrar como [aquela situação] era o microcosmo do medo instalado à escala nacional”. (JOSÉ, 1997, p. 1).

Nessa mesma Nota final, dividida em três partes, José Cardoso Pires acentua, ainda mais, o caráter de verossimilhança do crime, ao esclarecer que: 1- ele fez uma leitura posterior dos dois processos-crimes - o da Polícia Judiciária (PJ), e o da Polícia Política, a PIDE (Polícia Internacional de Defesa do Estado) a respeito do inquérito policial, bem como entrou, posteriormente, em contato direto com o autor do relato, depois de ele ter cumprido a pena por homicídio; 2- a confissão dele revela a permanência de sua "solidão vertical" depois da "experiência de terror", 20 anos depois do crime; 3- um ambiente de medo pairava em Portugal durante a ditadura salazarista e sua conclusão [do escritor] sobre o trágico evento e seu conteúdo que pode ser classificado pelo escritor como "material universal", mas, para alguns como "matéria história" e "matéria ficcional", para outros. (PIRES, 1982, p. 255 e 256).

O caráter de veracidade dos fatos narrados na obra polifônica é evidenciado pelo próprio autor:

Em certas vidas (eu acrescentaria, em todas) há circunstâncias que projectam o indivíduo para significações do domínio geral. Um acaso pode transformá-lo em matéria universal - matéria histórica para uns, matéria de ficção para outros, mas sempre justificativa de abordagem. Interrogamo-la, essa matéria, porque ele nos interroga no fundo de cada um de nós - foi assim que pensei esse livro, um romance. [...]. O Major Castro, o arquiteto Fontenova, o cabo Barroca e Mena são personagens literárias, dissertadas de figuras reais (PIRES, 1984, p. 246).

\section{$2.2 \mathrm{O}$ romance polifônico (Bakhtin)}

O conceito de polifonia, oriundo da linguística, é explicado pelo teórico da linguagem, Mikhail Bakthin (1895-1975), como a presença de outros textos em um texto, em diálogo com obras anteriores. O autor russo expande o termo para caracterizar um tipo de romance contraposto ao romance monofônico. Na obra Problemas da Poética da Dostoiévski, Bakhtin acentua que:

Dostoiévski é o criador do romance polifônico [...]. A voz do herói sobre si mesmo e o mundo é tão plena como a palavra comum do autor; não está subordinada à imagem objetificada do herói como uma de suas características mas tampouco serve de intérprete da voz do autor. Ela possui independência excepcional na estrutura da obra, é como se soasse ao lado da palavra do autor, coadunando-se de modo especial com ela e com as vozes plenivalentes de outros heróis. (BAKHTIN, 2008, p. 5) 
Para Dostoiéviski, “tudo na vida é diálogo, ou seja, contraposição dialógica". O escritor russo enfatiza que:

O romance polifônico é inteiramente dialógico. Há relações dialógicas entre todos os elementos da estrutura romanesca, ou seja, eles estão em oposição como contraponto [...]. Dostoiéviski teve a capacidade de auscultar relações dialógicas em toda a parte, em todas as manifestações da vida humana consciente e racional; para ele, onde começa a consciência começa o diálogo. (BAKHTIN, 2008, p. 47)

Portanto, para Bakhtin, no romance polifônico há uma estrutura dialógica na qual cada personagem atua como um ser autônomo com sua própria mundividência. Além de haver menção a outros tipos de registros.

O romance Balada da Praia dos Cães: Dissertação sobre um crime tem uma estrutura polifônica, mesclada com menções a obras diversas sobre a História contemporânea de Portugal, jornais de Lisboa, laudo necrológico, panfletos políticos da época, entre outros tipos de registros, como as declarações de personagens que conheciam os assassinos o e testemunho dos investigados durante a elucidação criminal.

A obra tem um paratexto inicial: CADÁVER DE UM DESCONHECIDO encontrado na Praia do Mastro em 3-4-1960 (ficha necrológica), seguido da página com o nome do autor e título da obra. Inicia-se a narrativa em terceira pessoa sobre as impressões a respeito do comportamento do animal que farejou o cadáver do militar e as condições do local na praia onde foi o mesmo foi encontrado. Prossegue com A investigação, 7 de maio de 1960, seguida de seis capítulos e encerra-se com A reconstituição, 8 de agosto de 1960. Como a suspeita Filomena foi detida pelo inspetor Manuel F. Otero e pelo agente de $1^{\text {a }}$ classe, Silvino Saraiva Roque, agentes da PJ, o chefe da brigada de homicídios, Elias Cabral Santana (Francisco Correia das Neves), foi o responsável por todas as diligências para a elucidação do crime. Depois dessa fase, os criminosos foram conduzidos para as dependências da PIDE, julgados e condenados. O romance encerra-se com um passeio noturno de Elias pelas ruas de Lisboa. Segue-se o Apêndice e a Nota final.

A preocupação de Cardoso Pires com a verdade do crime passional de 1960 (antecedentes, repercussão e bastidores da investigação) e com o contexto histórico da ditadura salazarista reflete-se na citação de obras consultadas para a escrita, fatos, envolvidos e delitos, mencionados no Apêndice: Portugal oprimido (1974) e Alvorada em Abril (1977), de Fernando Queiroga; Memórias do Capitão (1962), de Sarmento Pimentel, 
Documentos secretos da PIDE (1976), de Nuno Vasco, Relatório Stohrer do III Reich, Entrevista do Coronel Varela Gomes ao Diário de Lisboa, 1. Set. 1982, A Carta aos Generais (Lopes da Silva, Beleza Ferraz, J. Botelho Moniz e Costa Macedo, publicadas em Missão de Portugal (1963), de Álvaro Lins (CARDOSO PIRES, 1983, p. 251 a 254).

Balada da Praia dos Cães mescla diferentes registros: o científico-policial, o literário, o musical, o jornalístico (Diário de Notícias, O Século, Diário Popular e Diário da Manhã, de Lisboa; e Tribuna Popular, do Rio de Janeiro); bem como outros tipos de textos: o panfleto da Frente Armada Independente (F.A.I.), de anônimos Oficiais das Forças Armadas, em apoio ao líder, o major Dantas; um postal à PJ, com acusações à PIDE etc.

Vários dados mencionados no Apêndice dialogam com as informações do Caderno de Dantas C (o medo, o preço e a denúncia) e de sua lista negra que esboçava planos de fazer um acerto de contas com a inércia dos militares de alto escalão:

(A traição dos generais:

a) o medo: O presidente da República, marechal Carmona, encomendou um golpe de Estado para demitir o ditador Salazar mas desmentiu-se no dia seguinte.

O medo: Em operações de guerra o comandante Abrantes Silva ordenava um alto à marcha, reunia o pessoal à volta, obrigava-o a ajoelhar e comandava a oração: "Oremos, meus filhos!"

b) O preço: O general Pereira Lourenço e o irmão, director da Pide, compraram a Papelaria Fernandes, de Lisboa, e transformaram-na na grande empresa fornecedora das polícias e dos organismos do Estado.

O preço: "Só me comprometo com a revolução se me derem 1500 contos!" - General Ramires ao capitão F. Queiroga (1945).

c) A denúncia: $\mathrm{O}$ general Fernando de Oliveira, além do soldo militar e dos honorários de gerente da Sociedade Nacional de Sabões, recebia 5000 escudos mensais como informador da polícia política (Pide).

A denúncia: $O$ general da aviação Alfredo Sintra informador do Ministério dos Estrangeiros de Hitler.

A denúncia: O general Galvão de Melo conspirador com conhecimento de Salazar.

"O comodismo dos generais portugueses sujeita-os à chacota e à degradação.” Gen. Humberto Delgado, Carta aos Generais.

"General ou brigadeiro é tudo o mesmo chiqueiro."

"As estrelas dos generais não iluminam, cegam", Dantas C, Caderno.)

(PIRES, 1983, p. 196)

\section{$2.3 \mathrm{O}$ romance policial (Todorov)}


Dissertação sobre um crime, o subtítulo da narrativa, caracteriza-a como obra de investigação criminal. Em Tipologia do romance policial, Tzvetan Todorov classifica esse tipo de narrativa como 1-romance de enigma; 2-romance negro; e 3-romance de suspense.

O romance de enigma, romance policial clássico, que teve sua época de ouro entre a Primeira (1914-1918) e a Segunda Guerra Mundial (1939-1945), é constituído por duas histórias - a história do crime e a história do inquérito -, que tem duas séries temporais: a do passado (a do delito), e a do presente (a da investigação). O primeiro tipo de narrativa conta "o que se passou efetivamente", e o segundo explica "como o leitor (ou o narrador) tomou conhecimento dela". (TODOROV, 1970, p. 96-97).

Na primeira história, um crime é descoberto, e a sua característica é: "que ela não pode estar imediatamente presente no livro", ou seja, o narrador não pode transmitir nem as réplicas e nem os gestos das personagens envolvidas no delito, pois tal tarefa passa a ser intermediada pela personagem participante do crime ou por outra, em outra fase da narrativa. Nesse caso, um cadáver é encontrado com alguns indícios, e se busca a causa que levou ao dolo. O leitor fica curioso em saber a revelação do assassino.

A segunda história relata sobre "as palavras ouvidas ou os atos observados". Tal narrativa ampla, surgida durante as várias etapas do inquérito, é mediadora entre o leitor e a história do crime (TODOROV, 1970, p. 97). Ocorre um processo de elucidação do dolo, no qual as personagens descobrem o(s) culpado(s), e não agem. Por meio de interrogatórios, indícios e pistas, chega-se à descoberta do crime (prólogo da história), e à revelação do(s) assassino(s), (epílogo da história do inquérito). Esta é contada, geralmente, por um amigo do detetive, o qual tem imunidade, isto é, ele nem sofre perigo, ou ataque, nem é ferido ou morre (história do detetive invulnerável/ imunidade do detetive). E o mistério, o pretexto global da narrativa, está no primeiro plano. Trata-se da história desse livro escrito pelo autor/narrador e lido/analisado pelo leitor. As particularidades sobre o crime serão reveladas no final do romance.

Baseado nas vinte regras do romance policial anunciadas pelo escritor S.S. Van Dine (1828), Todorov as resumiu em oito pontos, passíveis de serem aplicados às caracterizações do romance de enigma e do romance negro. As quatro partes a seguir podem ser aplicadas à tipologia do romance de enigma (primeira história: a vida):

1. O romance deve ter no máximo um detetive e um culpado, e no mínimo uma vítima (um cadáver). 
2. O culpado não deve ser um criminoso profissional; não deve ser detetive; deve matar por razões profissionais.

3. O amor não tem lugar no romance policial.

4. O culpado deve gozar de certa importância:

a) na vida, não ser um empregado, nem uma camareira [...]. (TODOROV, 1970, p. 100-101).

Balada da Praia dos Cães tem evidências de ser um romance de enigma, a começar com a inclusão de um para-texto necrológico, CADÁVER DE UM DESCONHECIDO encontrado na Praia do Mastro em 3-4-1960, com quinze itens, que explica sobre o achamento de: "1. Indivíduo do sexo masculino, com 1,72 de altura, bom estado de nutrição, idade provável cinqüenta anos....", entre outros aspectos da condição do corpo e local, como:

2. não apresenta rigidez cadavérica; não tem livores...

3. Na calota craniana, ao nível da sutura dta. occipito-parieta, há uma perfuração circular de $4 \mathrm{~mm}$ de diâmetro provocada por projétil ... [...].

15. ausência de sinais de homossexualidade activa ou passiva... [...].

Ap. Exame 'in situ': [...].

Não foram encontrados documentos, haveres ou quaisquer referências pessoais. Nas regiões a descoberto algumas peças de vestuário apresentavam-se rasgadas pelos cães .... (PIRES, 1983, p. 5-6).

\section{Fato e irrealidade no romance híbrido de José Cardoso Pires}

Na Balada da Praia dos Cães, Cardoso Pires denúncia as arbitrariedades da ditadura salazarista, que amordaçou dissidentes, perseguiu, prendeu, torturou e matou, teve uma versão cinematográfica (1987).

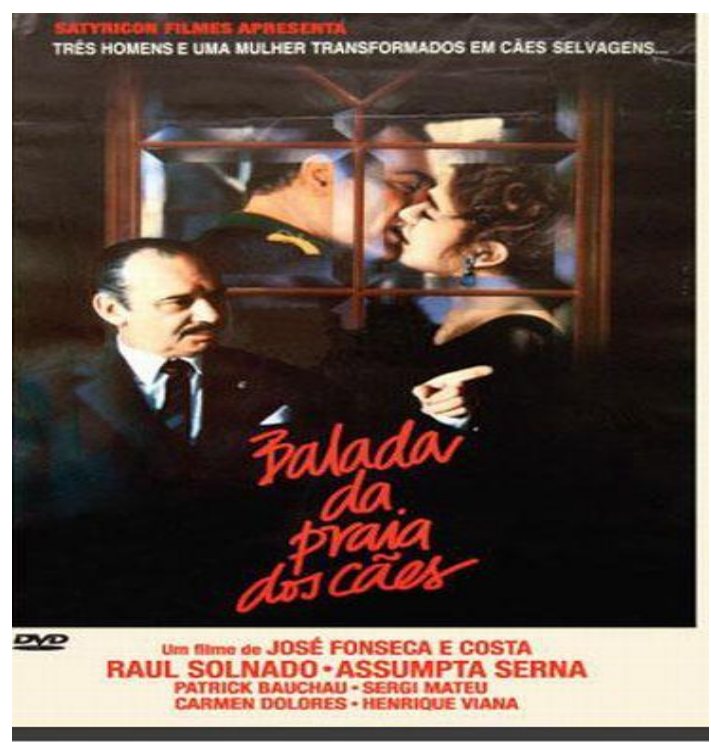

Fig. 2- Cartaz do filme Balada da Praia dos Cães (1987). Baseado no romance homônimo de Cardoso Pires. Direção de José Fonseca e Costa. Inspetor Elias (Raul Solnado), casal Dantas (Patrick Bauchau) e Filomena (Assumpta Serna). 
Na obra A palavra do romance: Ensaios de genologia e análise (1986), Maria Alzira Seixo comenta sobre as distintas configurações da narrativa portuguesa pós-1974:

Se as tendências regionalistas e universalistas se distribuíra na literatura moderna por vultos [...] e movimentos de grande impacto [...] a partir de 1974 é possível verificar uma reorganização destas várias tendências. [...] Esta escrita marcada de tempo procura abrir um espaço de descoberta ou pelo menos de compreensão: compreensão do sentido da liberdade enfim reencontrada (liberdade de ser, de existir, e por conseguinte também de escrever), compreensão do que essa realidade quer dizer e para onde ela vai (SEIXO, 1986, p. 73).

Em O uso político da memória na ficção de José Cardoso Pires, Izabel Margato acentua que:

Crime, suspeita, ambigüidade são ingredientes caros aos textos de Cardoso Pires. Pode-se dizer que o escritor chega a alimentar a impressão de que seus textos seriam do gênero policial. Muitos dos ingredientes desse gênero estão presentes em seus livros, a começar pelo narrador que, em muitos deles, veste ou toma emprestada a capa do detetive. Este é o caso do romance $O$ Delfim e também é o caso de um dos personagens principais da Balada da Praia dos Cães. No entanto, essa impressão é enganosa, trata-se muito mais de um movimento da sua ficção, isto é: a tática de quem faz da escrita um modo de decifração. (MARGATO, 2004, p. 1)

A obra Balada da Praia dos Cães, iniciada com um relato policial sobre a descrição do cadáver de um desconhecido (quinze itens com jargão criminalístico e de medicina legal), divide-se em: A Investigação 7 de Maio de 1960; A reconstituição 8 de Agosto de 1960; Apêndice e Nota final (setembro de 1982).

As equipes de investigação que elucidaram o caso fazem parte da Polícia Internacional de Defesa do Estado e da Polícia Judiciária. Membros da PJ, o inspetor Otero e o agente de $1^{\text {a }}$ classe, capturaram Filomena, e a investigação esteve sob a responsabilidade de Elias Santana e do agente Silvino Roque.

\subsection{A investigação (7 de maio de 1960)}

Estruturada em dois planos - o da investigação do homicídio e o da elucidação dos fatos entre a fuga de Dantas Castro e o achamento de seu corpo, realizado pelo detetive Elias e equipe - a narrativa revela uma atmosfera de medo e violência em Portugal. 
A trajetória de Elias Cabral Santana, protagonista do romance, não tem semelhança com a biografia de Francisco Correia das Neves, ${ }^{4}$ que investigou o assassinato, conhecido como o "Crime do Guincho". Elias é filho de juiz, cantor lírico amador em academias de bairro, é um "indivíduo de fraca compleição física, palidez acentuada, 1 metro e 73 de altura; olhos salientes [...]". Exibe a "unha do dedo mínimo, que é crescida e envernizada, unha de guitarrista ou de mágico vidente, e que faz realçar o anel de brasão exposto no mesmo dedo", e usa habitualmente um casaco xadrez, calça lisa, e gravata de luto guarnecida com alfinete de pérola. Conhecido por Covas ou Chefe Covas, Elias tem esse apelido por causa de sua prestação de serviços na Seção de Homicídios, e por ter passado: "a vida a desenterrar mortes trabalhadas e a distribuir assassinos pelos vários jazigos gradeados que são as penitenciárias do país". Utiliza o termo De Cujus, ao invés das palavras: defunto, finado ou falecido. (PIRES, 1983, p. 13-14)

No início do romance Balada da Praia dos Cães, o narrador indica uma das possibilidades do esclarecimento do crime, ao comentar a notícia veiculada em um jornal de Lisboa: "E estes são os três suspeitos, os que mataram e levaram o segredo com eles." (PIRES, 1982, p. 17). Em posse do periódico, Elias analisa as fotos dos acusados e lê:

[...] uma vez que tendo sido posta de parte a hipótese de crime sexual a princípio admitida, todos os indícios recolhidos, indicam estar-se em presença de um assassinato político. O facto de o cadáver ter sido calçado com os sapatos trocados é por si só revelador, pois constitui uma prática de execução dos traidores entre os grupos clandestinos (PIRES, 1983, p. 17)

Solitário, órfão de pais, com uma única irmã, já falecida, Elias, 41 anos, que tem como bicho de estimação o lagarto Lizardo, durante a investigação, apaixona-se pela suspeita Filomena, desde que viu as fotos dela encontradas em seu apartamento, quando foi vistoriado em busca de indícios que poderiam elucidar seu envolvimento com o major Dantas e o seu assassinato:

[...] Elias advinha esse corpo. Um corpo sumptuoso; todo no concreto, cada coisa no seu lugar. Admira-o em particular numa foto em que ela aparece em bikini num relvado de piscina com um friso de pavões ao

\footnotetext{
${ }_{4}^{4}$ Aos 30 anos e recém-nomeado inspetor da Polícia Judiciária de Lisboa, Francisco Correia das Neves (19292017) foi designado para investigar o assassinato do capitão Almeida Santos. Sua experiência no caso o levou a publicar O Crime do Guincho, em 2004. Formado em Direito pela Universidade de Coimbra (1955), Neves foi delegado do Procurador da República e atuou nas comarcas de Serpa, Cuba e Alcobaça. Foi deputado na Assembleia Nacional, nos anos 1969 a 1973, onde lutou pela anistia de presos políticos.
} 
fundo - e era uma verdade, aquele corpo. Coxas serenas e poderosas, o altear do púbis, era isso, era essa verdade saudável e repousada que [...] contemplava apoiado num cotovelo. (PIRES, 1982, p 28).

Como chefe da brigada da Polícia Judiciária (PJ), Elias, que se faz acompanhar pelo agente Silvino Roque nas diligências, não investigou o homicídio sozinho, pois pelo fato do crime ter sido considerado político, houve o inquérito realizado também pela equipe da PIDE.

$\mathrm{Na}$ Casa da Vereda, local de refúgio dos quatro - Dantas Castro, o arquiteto Fontenova, o cabo Barroca e Filomena -, a ambiência assume a dimensão de desespero e de terror quando percebem que estão esquecidos e encurralados. O líder bebe desenfreadamente e, como um desvairado, aterroriza os demais. Debocha de Barroca, que tenta estabelecer uma rotina normal no cotidiano tenso e estuda francês com Fontenova, na crença ingênua de que iriam para a França, país de seu sonho de emigração. Dantas atormenta o arquiteto para romper o vinculo com o cabo:

"Posso Dantas?" E disse-as. E lembrou que não tinha sido ele,
Fontenova, quem aliciara o cabo com promessas de o por no lado de lá
da fronteira e que isso é que é em seu entender representava um logro
para o rapaz, intencional ou não. Que não tendo havido até aquela data
quaisquer sinais de actividade também não seria a melhor altura para o
convencerem a integrar-se na luta revolucionária. Pelo contrário
Fontenova receava que o cabo se sentisse traído e então, sim,
desaparecesse ou fizesse alguma imprudência. (PIRES, 1983, p 193).

Nesse momento de amarga constatação de sentimento de perda total dos sonhos de democracia, de liberdade, de igualdade e de fraternidade, bem como da falta de dinheiro, e da não ajuda com documentos falsos para a fuga, a união entre eles começa a ruir completamente. Fora compreendido que Dantas, disfarçado de padre, quando afirmava visitar o Comodoro, o advogado Sá, que era o vínculo de ligação com a realidade, de fato, se abrigava nas imediações da casa-esconderijo. Diante do arrependimento pela participação no funesto plano de fuga de Elvas, arquitetado pelo major e apoiado pela desequilibrada Mena, ficou evidente somente uma verdade para Fontenova e por Barroca: a saída individual do esconderijo e/ou a eliminação do mentiroso tirano. Eram planos complicados e que provocaram a tragédia na noite de ameaças protagonizada por Dantas.

No fatídico dia, o major organizou um tribunal militar, no qual atuou como juiz e promotor: na chamada "Noite dos Generais", ele fez revelações verbais sobre a corrupção 
encalacrada nos altos escalões do Exército, já escritas em uma brochura (Dantas C. Caderno) que foi achada pela polícia. No quarto, ele começou, com a lâmpada acesa, a torturar Mena que logrou escapar. Cientes do plano divulgado por ele, anteriormente, sobre o assassinato da moça, cujo local da cova tinha sido mostrado, bem como sobre o risco de suas próprias vidas, conforme ficou muito claro naquele momento pelas atitudes e ameaças do "juiz" implacável, os dois jovens planejam o assassinato, executado com tiros e golpes de pá.

\subsubsection{Os depoimentos de Filomena: A clandestinidade e a "Noite dos Generais"}

Filomena Joana Van Niel Athaíde, filha única de um engenheiro e de mãe alcoólatra falecida, era uma estudante universitária viciada em tabaco e Valium. O elo de amor-ódio entre Mena, 23 anos, e seu amante controlador, Luís Dantas Castro, 41 anos, conhecido de seu pai desde Moçambique, tinha sido sempre pautado pela violência física e verbal, conforme testemunhos de vizinhos do apartamento que ele tinha montado para encontros amorosos. Conforme as queixas da proprietária do imóvel, que tinha sido abandonado com aluguel atrasado, a faxineira tinha visto frases obscenas escritas nas paredes e portas do mesmo, como "SOU UMA PUTA PORCA". (PIRES, 1983, p. 161-162).

No princípio do inquérito, quando Mena foi aprisionada, depois de uma denúncia da telefonista do Novo Hotel, que a reconhecera pelas fotos do jornal, ela narra ao investigador a tirania exercida pelo militar no esconderijo, e sem pestanejar, confessa o crime: "Elias acompanha a cena para lá do esmaecer das lentes mas o seu ouvido de polícia registra-a na versão definitiva: Impossibilitada de se libertar, a acusada fez ali mesmo a confissão circunstanciada dos acontecimentos". (PIRES, 1983, p. 197).

A moça sabia dos planos de golpe de estado, que provocaram a expulsão de Dantas do Exército e o seu aprisionamento. Fiel e dedicada, acompanhou-o de perto em seu confinamento no presídio militar de Elvas e foi cúmplice no plano de fuga e na vida clandestina: alugou a residência para esconderijo; comprou um traje de padre para ser usado como disfarce por Dantas; buscou os fugitivos com um carro, na noite chuvosa; fazia o serviço doméstico na casa; comprava mantimentos e outros objetos; visitou o advogado Sá; e tentava animar o depressivo e embriagado amante.

Submissa a ele desde o início do relacionamento complicado, sofreu diversos tipos de maus tratos, contínuos, dolorosos e ritualísticos, próprios de uma relação sado-masoquista, como os ocasionados com pontas de cigarro aceso, que atingiram o ápice quando ele 
queimou seu rosto com a luz flamejante de um abajur, no esconderijo. Mas durante o interrogatório, envergonhada, ela tenta explicar a Elias que Dantas era impotente, pois como muitas mulheres agredidas fisicamente e emocionalmente, absolvem o companheiro e suas atrocidades e, nesse caso, com a desculpa de uma falha sexual, como justificativa simplista sobre o papel de carrasco que ele desempenhava em sua existência sem significado pessoal: uma vida à sombra do major.

Durante o tenso e repetitivo interrogatório, Filomena conta a Elias sobre seu temor de ser assassinada pelo amante, revelando indícios assustadores a respeito do tipo de tormento psicológico e físico que estava sofrendo nas mãos dele, desde os encontros no apartamento por ele alugado até as sessões intensificadas na Casa da Vereda, onde se revelou um verdadeiro psicopata, queimando suas costas e seu rosto.

$\mathrm{Na}$ noite do crime, Mena foi para o quarto e o major a seguiu. Ele a agarrou pelo pescoço, interrogando-a sobre a procedência do dinheiro, que na verdade Fontenova tinha conseguido com a mãe, para a subsistência da casa. Aos berros, ameaçava cegá-la com o candeeiro, mas ela conseguiu se safar, refugiando-se no banheiro: "Conta que ia despida e que se fechou ali talvez durante meia hora, sentada na sanita por se sentir à beira do desmaio. Tinha as faces em fogo e inchadas". (PIRES, 1982, p. 197-198). Ela prosseguiu:

[...] As torturas, diz. Cada vez ia mais longe, tinha de acabar por me matar.

Então põe-se de pé, e olhe, volta-se levantando as traseiras do pull-over acima do elástico do soutien. E Elias vê. Vê e não acredita. Desde a cintura ao pescoço tinhas as costas lavradas por queimaduras de cigarro, cinzentas e eriçadas. Repetidas. Meticulosas. Pareciam uma espinha de escamas a todo o correr do dorso.

Ele tinha-se tornado impotente, diz Mena, baixando o pull-over. (PIRES, 1983, p. 217).

\subsection{A reconstituição do homicídio (8 de agosto de 1960)}

Os cúmplices no assassinato, Renato Manuel Fontenova Sarmento, alferes miliciano e arquiteto, 25 anos, e Bernardino Barroca, $1^{\circ}$ cabo, 22 anos, eram solteiros e desertores do exército português. Foram presos no Motel Marina, Praia Azul, Algarve, levados para a Penitenciária de Lisboa e interrogados pelo agente Mortágua, que serviu de escrivão, e pelo inspetor Falcão da PIDE. Elias leu os dossiês.

No dia 8 de agosto de 1960, os réus foram até a Casa da Vereda para detalhar o crime. Fontenova mostrou para Elias onde seria enterrado o corpo de Filomena, segundo 
Dantas, e falou das torturas que ela sofria nas mãos do amante. Barroca indicou para o agente Roque, onde o major escondia-se, quando deveria estar reunido com o advogado.

Nos detalhados relatórios de Elias destacam-se episódios das revelações de Fontenova sobre o desequilíbrio do líder e seus planos grandiosos para destruir símbolos funestos do poder:

"Foi-lhe então dito pelo major que começariam por agitar o país provocando uma série de incêndios que designou por políticos. Acções sempre espetaculares e fáceis de realizar por não requererem pessoal treinado. Entre os locais escolhidos recorda-se de ter ouvido nomear o cinema São Luís (por ficar contíguo à sede da Pide) e os edifícios do Diário da Manhã e do Tribunal Militar, o primeiro porque continha matéria inflamáveis e o segundo porque, além de ser construção antiga, era em grande parte ocupado por arquivos. No que respeita às individualidades a abater o major não referiu o método que se propunha utilizar." (Arq. Fontenova, uma vez, mais.) (PIRES, 1983, p. 227 e 228)

Durante a reconstituição do assassinato, foi revelado que depois dos tiros efetuados pelos réus, Filomena acreditou que Dantas ainda estaria vivo. Fontenova lhe passou a arma:

E Mena não sentiu repulsa nem estranheza ao pegar na pistola. Obedeceu talvez por um instante de companhia, não é fácil explicar. Ou por habituação à morte, nem sabe. Afinal ia disparar sobre um cadáver para dar sossego a dois vivos; a três, ela também contava. $\mathrm{O}$ arquitecto pegou-lhe no pulso para orientar na pontaria, com a outra mão envolveu a dela e pressionou-a sobre o dedo que comandava o gatilho. Mena nunca mais se esqueceria da frieza macia que respirava essa mão e do apagamento com que ele lhe ajustou aos dedos. Por isso a olhou e não ao alvo no acto de disparar. (PIRES, 1983, p. 233-234)

Logo após o assassinato, Filomena começou a dormir com Fontenova no esconderijo.

\section{Conclusão}

Pela publicação de Balada da Praia dos Cães (1982), oito anos depois da queda do regime ditatorial de Portugal (1974), José Cardoso Pires foi agraciado com o Grande Prémio do Romance e da Novela, outorgado pela Associação dos Escritores Portugueses, no mesmo ano.

O romance histórico-policial tem peculiaridades próprias, pois é baseado em um fato verdadeiro, e o autor utilizou vários tipos de registros (BAKHTIN), que caracterizam a ruptura com os paradigmas do romance tradicional, para dar veracidade à ação. A ficção e a 
história, segundo Hutcheon, são discursos que dão significado ao passado. (HUTCHEON, 1991, p. 122)

O narrador faz descrições detalhadas da cidade de Lisboa, imersa em medo, como forma de crônica da morosidade e homogeneidade da vida de pessoas em um sistema ditatorial, exercido com controle e punição. A presença simbólica de Salazar, como encarnação da ditadura, está presente em retratos pendurados nas repartições públicas e nas ramificações visíveis e subterrâneas da Polícia Judiciária e da Política Internacional e de Defesa do Estado.

Cardoso Pires tece inúmeras e profundas descrições psicológicas a respeito da personalidade dos envolvidos no crime, da vítima e de Elias, para melhor compreensão de suas atitudes. O narrador destaca, em especial, o perfil do detetive, que guardou, para si, em um "baú de sobrantes", fotos da homicida, notícias sobre o crime etc.

Os dados do relato policial sobre o corpo e o crime fazem parte da "primeira história", a "história do crime", e a sua continuação/aprofundamento caracterizam a "história do inquérito" (romance de enigma (TODOROV, 1970).

O escritor dá vOz a várias pessoas, que narram as várias versões para a reconstrução do crime e fazem parte dos autos do processo e do dossiê organizado por Elias e por Otero (Polícia Judiciária). A pluralização discursiva soa na balada política, como vozes anônimas e nomeadas que condenam, indiretamente, a opressão da ditadura portuguesa, capaz não somente de amordaçar seus críticos, escutar clandestinamente, encarcerar, condenar, e matar, mas de contribuir para que pessoas normais, que anteriormente não tinham exibido traços de violência em suas atitudes, possam se tornar assassinas frias.

José Cardoso Pires humaniza personagens históricas, como o detetive, bem como a vítima e os assassinos - dois homens e uma mulher -, apresentando as várias facetas de suas personalidades, com destaque para as fragilidades emocionais, que culminaram no homicídio premeditado do militar, considerado um modelo de retidão e liderança política, que se metamorfoseou em um tirano frente aos seus cúmplices, ao instalar um microcosmo ditatorial no esconderijo, a Casa da Vereda.

\section{BIBLIOGRAFIA}


BAKHTIN, Mikhail. Problemas da Poética da Dostoievski. Trad., notas e prefácio de Paulo Bezerra. Rio de Janeiro: Forense Universitária, 2008.

BALADA DA PRAIA DOS CÃES, 19 jan. 2012. [Acórdão da Secção Criminal do Supremo Tribunal de Justiça de 2 de maio de 1962]. Disponível em: <http://malomil.blogspot.com/2012/01/acordao-da-seccao-criminal-do-supremo.html>. Acesso em: 18 mai. 2018.

HUTCHEON, Linda. Historicizando o pós-moderno: a problematização da história. In: Poética do pós-modernismo: história, teoria, ficção. Trad. de Ricardo Cruz. Rio de Janeiro: Imago, 1991.

MARGATO, Izabel. O uso político da memória na ficção de José Cardoso Pires. Revista Semear, 10, 2004. Disponível em: <

http://www.letras.puc-rio.br/unidades\&nucleos/catedra/revista/10Sem_07.html>.

Acesso em: 7 de abril 2018.

MENESES, Filipe Ribeiro. Salazar: biografia definitiva. Trad. de Teresa Casal. São Paulo: Leya, 2011.

MOISÉS, Massaud. Dicionário de termos literários. $12^{\mathrm{a}}$ ed. ver. e ampl. São Paulo: Cultrix, 2004.

PIMENTEL, Irene. O Golpe da Sé. Blog, 19 de abril de 2010. Disponível em:

<http://irenepimentel.blogspot.com.br/2010/04/o-golpe-da-se.html>. Acesso em: 7 de abril 2018.

PIRES, José Cardoso. Balada da Praia dos Cães: Dissertação sobre um crime. $8^{\mathrm{a}}$. ed. Lisboa: Círculo de Leitores, 1983.

PIRES, José Cardoso. Entrevista. Expresso, Lisboa, p. 1 e 2, 20 dez. 1997.

PIRES, José Cardoso. O meu romance é uma valsa de conspiradores. Entrevista a Antonio Mega Pereira. Jornal das Letras, Lisboa, ano II, n. 47, p. 2 - 4, 7 dez. 1982.

SECCO, Lincoln. A Revolução dos Cravos e a crise do império colonial português: economias, espaços e tomadas de consciências. São Paulo: Alameda; USP; FAPESP; Instituto Camões/ Cátedra Jaime Cortesão, 2004.

SENA, Jorge de. Editorial: Dois cadáveres, Portugal Democrático, Lisboa, p. 1, abril 1960. Disponível em: <http://www.letras.ufrj.br/lerjorgedesena/port/antologia/declaracoespublicas/texto.php?id=98>. Acesso em: 7 de abril de 2018 . 
SEIXO, Maria Alzira. A palavra do romance: Ensaios de genologia e análise. Lisboa: Livros Horizonte, 1986.

TODOROV, Tzvetan. "Tipologia do romance policial". In: As estruturas narrativas. Tradução s.n. 2. ed. São Paulo: Perspectiva, 1970. p. 93-104.

\section{Iconografia}

Fig. 1- Capa do romance, Editora Círculo do Livro, 1991. Disponível em: $<$ https://www.estantevirtual.com.br/releiturascentro/jose-cardoso-pires-balada-da-praiados-caes-1015590251>. Acesso em: 7 de abril de 2018.

Fig. 2- Cartaz do filme Balada da Praia dos Cães (1987). Baseado no romance homônimo de Cardoso Pires. Direção de José Fonseca e Costa. Inspetor Elias (Raul Solnado), casal Dantas (Patrick Bauchau) e Filomena (Assumpta Serna). Disponível em: < https://www.themoviedb.org/movie/270778-balada-da-praia-dos-c-es>. Acesso em: 7 de abril de 2018. 